\title{
Optimization of Mannanase Enzymes Production from Bacillus cereus V9 Using Local Mannan Substrate
}

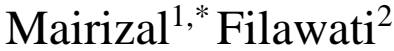 \\ ${ }^{12}$ Animal Science Faculty, Universitas Jambi, Jambi - Indonesia \\ ${ }^{*}$ Corresponding author. Email: filawatis.ptmp@yahooo.com
}

\begin{abstract}
Bacillus cereus V9 is a mannanolytic bacteria capable of producing a mannanase enzyme of $29.5 \mathrm{IU} / \mathrm{mL}$ with a substrate of Locust bean gun. The use of Locust bean gum as a substrate in the production of the enzyme mannanase is not recommended because it is expensive so that the enzyme produced will be expensive. The use of local mannan substrates such as porang, coconut pulp, coconut cake, and palm kernel meal has the opportunity to replace Locust bean gum because the mannan content is almost equal to the content of the mannan Locust bean gum so the resulting enzyme is cheaper. This study aims to determine the best local mannan biomass substrate as a substitute for Locust bean gum for the production of the mannanase enzyme from Bacillus cereus V9 bacteria. This study consisted of two stages where the first stage was the optimization of the production of mannanase enzymes in various alternative substrates for Locust bean gum, then the second stage was the production of the enzyme mannanase from the selected substrate as a substitute for Locust bean gum. Simple data analysis is based on calculating the number and average of each observation from 4 replications and the data is displayed in the form of a descriptive narrative. The results showed that Bacillus cereus V9 could grow on all local mannan media and the highest was on palm kernel meal media. The growth of Bacillus cereus V9 at a substrate concentration of $1 \%$ palm kernel meal did not differ from a concentration of $1.5 \%$ and $2 \%$. The activity of the mannanase enzyme Bacillus cereus V9 in palm kernel meal media was higher when compared to porang, coconut cake, and coconut pulp. This study concludes that palm kernel meal can be used as a $1 \%$ substrate as a substitute for Locust bean gum in the production of the enzyme mannanase from Bacillus cereus V9.
\end{abstract}

Keywords: palm kernel meal, porang, coconut meal, coconut cake, Locus bean gum, mannanase.

\section{INTRODUCTION}

The mannanase enzyme is an enzyme that plays an important role in breaking down mannan into mannose and mannan-oligosaccharide (MOS) [1]. Mannanase enzymes are widely used in the paper industry, as a hydrolytic agent in the detergent industry, in the hydrolysis of coffee extracts, in the improvement of animal feed, like a fish feed additive, as a mucus control agent, and in the pharmaceutical industry [2]. Several research results show that the addition of the mannanase enzyme either directly or through pre-treatment can reduce the crude fiber content of palm kernel cake so that it can improve its quality as animal feed [3][4][5][6][7].

Mannanase enzymes can be produced from bacteria, plants, fungi, and invertebrates ${ }^{4}$. The production of mannanase enzymes from microorganisms is superior because the production process is fast, the production conditions are more controlled, and the quality is uniform
[8]. One of the microorganisms that can produce the mannanase enzyme is the bacterium Bacillus cereus V9 [9].

Bacillus cereus V9 is a mannanolytic bacteria isolated from the digestive tract of termites which is capable of producing mannanase enzymes on Locust bean gum (LBG) substrate with the enzyme activity of $29.5 \mathrm{U} / \mathrm{mL}^{9}$. According to Sumardi et al.[10] the production of the enzyme mannanase usually uses a pure mannan substrate as a carbon source such as LBG. The use of LBG as a substrate requires a large amount of money because it is expensive and difficult to obtain in the market. This condition provides an opportunity for the local mannan substrate to be used as the main carbon source to replace LBG in the production of mannanase enzymes so that the production costs will be cheaper.

In Indonesia, there are various types of plants and byproducts from agroindustry which contain quite high levels of mannan, which can be used as a carbon source 
in the production of the enzyme mannanase. Porang, coconut cake, coconut pulp, and palm kernel meal are the by-products of agro-industry which contain high enough mannan to replace LBG as a substrate for microbial growth in producing enzymes. LBG contains $80 \%$ mannan while $78 \%$ palm kernel meal, $69.36 \%$ porang, $61 \%$ coconut cake, and $61.8 \%$ coconut pulp[ 11][1].

Optimization of enzyme production from microbes is largely determined by the type of substrate that will be used as a carbon source for growth and the length of incubation for microbes to produce enzymes [12]. Meanwhile, Sumardi et al. ${ }^{10}$ stated that the mannanase enzyme activity from bacteria would be optimized by paying attention to the concentration of the substrate used, the $\mathrm{pH}$, and temperature of the media during the microbial fermentation process [13]. Therefore, for optimization in the production of the mannanase enzyme from Bacillus cereus V9 using a local mannan substrate, it is necessary to pay attention to the factors mentioned above so that a more economical and practical enzyme will be produced.

\section{RESEARCH METHOD}

\subsection{Isolate Rejuvenation}

The rejuvenation of Bacillus cereus V9 bacteria was carried out by growing it in Nutrient Broth (NB) liquid media by adding $0.5 \%$ locust bean gum. Subsequently, it was incubated in a shaker incubator for 48 hours with a rocking speed of $130 \mathrm{rpm}$ at room temperature. The grown bacteria were transferred to solid media containing $0.5 \%$ locust bean gum and $1.5 \%$ bacto agar, $0.05 \%$ yeast extract, $0.075 \%$ peptone, and the minerals Mendels and Sternberg[14]. Then it was incubated for 24 hours and then the bacteria were ready to be used as stock for multiplying microbes.

\subsection{Selection of Local Mannan Substrate as a Substitute for Pure Mannan Substrate (LBG)}

The media used for the production of the mannananase enzyme from Bacillus cereus V9 was a liquid medium containing $1.5 \%$ bacto agar, $0.05 \%$ yeast extract, $0.075 \%$ peptone, $0.5 \%$ for each substrate (Locust bean gum (LBG) as control, porang (PR), coconut pulp (CP), coconut meal (CM) and palm kernel meal(PKM) ) and minerals Mendel and Stenberg ${ }^{14}$. The liquid media was made into two parts, namely for the pre-culture media as much as $30 \mathrm{~mL}$ of $100 \mathrm{~mL}$ natural erlemayer and $300 \mathrm{~mL}$ of culture media which were placed in the $500 \mathrm{~mL}$ erlemayer. All materials were dissolved in distilled water on each layer according to the substrate used and then sterilized in autoclave at a temperature of $121^{\circ} \mathrm{C}$ and a pressure of 1 atm for 15 minutes.

The rejuvenated bacteria were inoculated aseptically on pre-culture media for 3 ose then incubated in a shaker incubator for 24 hours. The precultures that had been grown with Bacillus cereus V9 were then transferred to culture media aseptically and again incubated for 120 hours. Harvesting of bacteria was carried out every 8 hours as much as $4 \mathrm{~mL}$ where $2 \mathrm{~mL}$ was used to measure microbial cell growth while $2 \mathrm{~mL}$ was used to measure the activity of the crude extract enzyme. Mannanase enzyme crude extract was obtained from cell culture extraction by centrifugation at a speed of $12,000 \mathrm{rpm}$ for 15 minutes. Then the supernatant obtained is ready to be used for measuring the activity of the mannanase enzyme.

The growth patterns of bacteria were measured by reading at a wavelength of $660 \mathrm{nM}$. Whereas the measurement of the activity of the mannanase enzyme was based on Meryandani et al [15], by incubating 0.5 $\mathrm{mL}$ of mannanase enzyme crude extract solution with $0.5 \%(\mathrm{w} / \mathrm{v}) \mathrm{LBG}$ substrate in a buffer phosphate solution $\mathrm{pH} 6$ at $30^{\circ} \mathrm{C}$ for 30 minutes. Then the reaction is stopped by immersing the test tube in boiling water (temperature $90^{\circ} \mathrm{C}-100^{\circ} \mathrm{C}$ ) for 20 minutes. Reducing sugar released was measured using the DNS method [16] then the color formed was measured using a spectrophotometer at a wavelength of $540 \mathrm{nM}$. One unit of the mannanase enzyme is defined as the amount of the mannanase enzyme which can produce $1 \mu \mathrm{mol}$ of reducing sugar (mannose base) for 1 minute. At this stage, the pattern of bacterial growth and the highest mannanase enzyme activity will be obtained on the selected substrate and for further optimization of the enzyme production on the selected substrate.

\subsection{Optimization of Selected Substrate Concentrations and Incubation Time.}

After obtaining the selected substrate to replace LBG in the production of the mannanase enzyme from Bacillus cereus V9, then the substrate concentration was optimized with 4 concentration levels, namely $0.5 \%, 1 \%$, $1.5 \%$, and $2 \%$. The liquid media used is the same as the media for substrate selection, but the substrate used is the substrate chosen to replace LBG. The procedure for measuring microbial cell growth and enzyme activity is also the same as for the determination of local mannan substrate selection as a substitute for pure mannan substrate (LBG). At this stage, the optimal concentration and incubation time will be obtained in the production of the enzyme mannanase using the selected substrate.

\subsection{Data analysis}

Data collection in the first stage of research is based on calculating the number and average of each observation from 4 replications and the data is displayed in the form of a descriptive narrative [17]. 


\section{RESULTS AND DISCUSSION}

\subsection{Selection of local mannan substrate as a substitute for $L B G$ in the production of the enzyme mannanase}

The rejuvenated Bacillus cereus V9 bacteria were then grown on various local mannan substrates showing different growth patterns from the locust bean gum substrate. The growth pattern of Bacillus cereus V9 in various substrates can be seen in Figure 1.

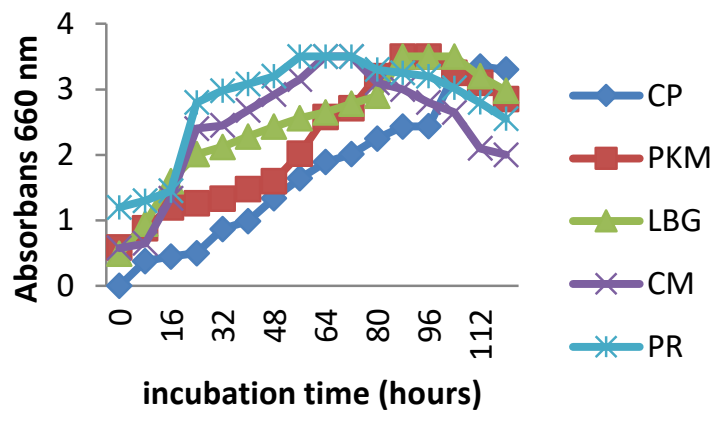

Figure 1. The Growth of Bacillus cereus V9 cells on various local mannan substrates.

The growth curve of Bacillus cereus V9 cells on porang substrate reached the peak point of cell growth faster than other local mannan substrates. Then followed by the substrate of coconut cake, locust bean gum, palm kernel meal, and coconut dregs. The results of this study indicate that the use of local mannan substrate as a substitute for LBG substrate can be used as a source of nutrition for the Bacillus cereus V9 bacteria. One of the essential nutrients for bacterial cell growth is carbon which will be used for growth and replication processes. According to Greg and Ricahad ${ }^{18}$ that bacteria will obtain carbon from the enzymatic breakdown of complex organic molecules such as carbohydrates.

The substrate is very important for cells for biomass growth, cell maintenance and to produce products from its breakdown. The type of substrate used for bacterial growth is usually adjusted to the type of enzyme to be produced. The incubation time in substrate fermentation shows a relationship between the use of the substrate and the production of the enzymes produced, where the production of enzymes decreases in line with the reduced availability of nutrients in the substrate [19]. Mannanase is the primary metabolite needed to break down the mannan contained in the substrate used by bacteria for their growth. In the initial phase, it was seen that Bacillus cereus V9 had not produced much mannanase because they still used other sources of nutrition from yeast extract as a nitrogen source. Bacteria will take advantage of the mannan present in the substrate after entering the exponential phase which is indicated by an increase in the production of the enzyme mannanase. According to Chen ${ }^{20}$ that yeast extract is generally used as a stimulator for microbial growth.

Mannan is a polysaccharide compound or complex carbohydrate that is difficult for cells to digest directly. Mannan will be degraded into simple sugars such as mannose and oligosaccharides by bacteria by secreting a mannanase enzyme. The activity of the mannanase enzyme from Bacillus cereus V9 on various local mannan substrates can be seen in Figure 2.

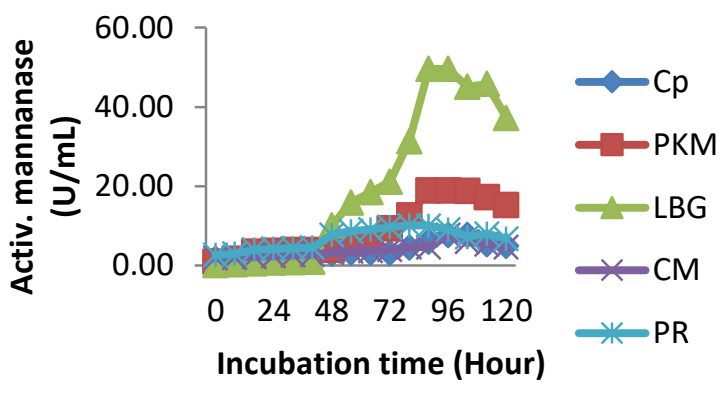

Figure 2. The activity of the mannanase Bacillus cereus V9 on the local mannanase substrate

The activity of the Bacillus cereus V9 mannanase enzyme on palm kernel cake media showed the highest activity when compared to other local mannan media. The activity of the mannanase enzyme Bacillus cereus V9 in palm kernel meal media reached 18,95 U/ mL from the $88^{\text {th }}$ hour to the $104^{\text {th }}$ hour. The high mannan content in palm kernel meal which reaches $30-70 \%{ }^{21,22,23}$ causes bacteria to produce mannanase enzymes in large quantities to degrade mannan being a much simpler compound. Chuan et al.[24], reported that palm kernel meal can be used as a substrate for the production of the enzyme manananase from Bacillus subtillis ATCC3366 with a mannnase activity of $8 \mathrm{U} / \mathrm{mL}$. Norizan et al.[25], also reported the use of palm kernel meal as a substrate to produce the enzyme mannanase produced from Bacillus subtillis ATCC11774. Thus, the results of this study indicate that palm kernel meal has a great opportunity as a substrate to replace locust bean gum for the production of the enzyme mannanase by Bacillus cereus V9.

\subsection{Optimization of Palm Kernel Meal Concentration as Substrate}

Based on the ability of Bacillus cereus V9 to produce mannanase enzymes on various local mannan substrates, palm kernel meal was chosen as an alternative substrate to replace locust bean gum. Although the mannanase enzyme activity of Bacillus cereus V9 was not as good as that of the locust bean gum medium, it had better activity than other local mannan substrates. Optimization of 
mannanase production from Bacillus cereus V9 using mannan substrate increased with increasing concentration of palm kernel meal. The growth of Bacillus cereus V9 bacteria at various concentrations of palm kernel meal substrate can be seen in Figure 3 .

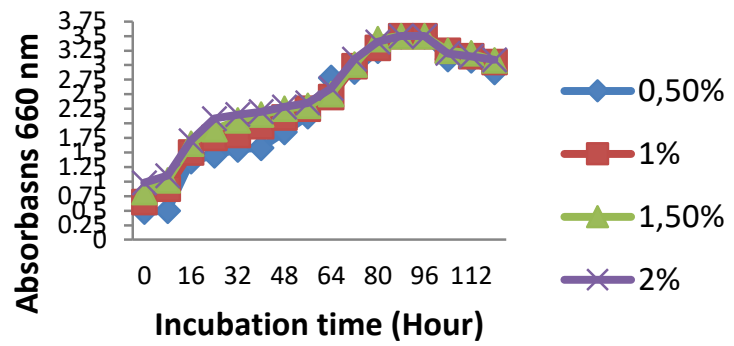

Figure 3. Growth of Bacillus cereus V9 at various concentrations of Palm Kerneal Meal

The growth of Bacillus cereus V9 at various concentrations of palm kernel meal substrate showed the same growth pattern. The bacterial growth rate reached its optimum point at the $88^{\text {th }}$ hour to the $96^{\text {th }}$ hour then decreased until the $120^{\text {th }}$ hour. The bacterial growth curves formed to coincide with each other at 56 to 120 hours. Nevertheless, the results of the analysis of the mannanase enzyme activity from various substrate concentrations showed that the $1 \%$ palm kernel meal substrate concentration had a higher enzyme activity value than other concentrations, reaching $30.25 \mathrm{U} / \mathrm{mL}$ (Figure 4).

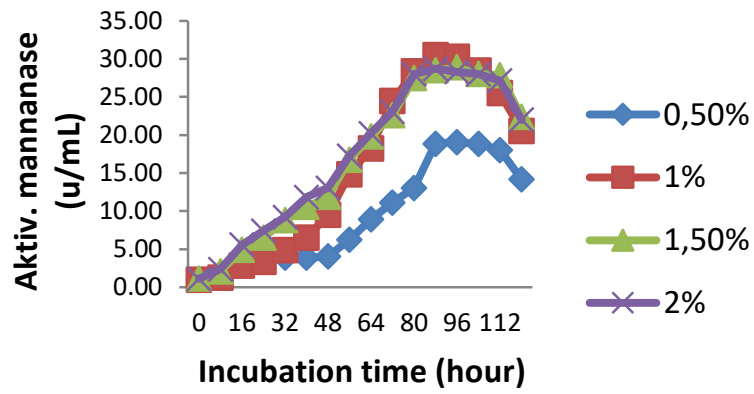

Figure 4. The activity of the mannanase enzyme Bacillus cereus V9 at various PKM concentrations

The results of the analysis of the mannanase enzyme activity showed that at the optimization stage the substrate concentration showed that the PKM substrate concentration was $1 \%$ higher than the concentration of $0.5 \%, 1.5 \%$, and $2 \%$. The activity value of the mannanase enzyme at $1 \%$ substrate concentration at the 88th hour reached $30.25 \mathrm{U} / \mathrm{mL}$ while for concentrations of $0.5 \%$, $1.5 \%$ and $2 \%$ were $18.85 \mathrm{U} / \mathrm{mL}, 28.50 \mathrm{U} / \mathrm{mL}$ and 28.69 $\mathrm{U} / \mathrm{mL}$. At a substrate concentration of $0.5 \%$, it was seen that the enzyme reached its peak production at the $88^{\text {th }}$ hour and almost simultaneously with other substrate concentrations, but had a lower value. Whereas at a higher substrate concentration $(2 \%)$, the mannanase activity value was lower than the $1 \%$ substrate concentration. A high substrate concentration will cause the solubility of oxygen in the water to be low because the viscosity increases, thus inhibiting bacterial growth. High viscosity will reduce the ability of the enzyme to break the bonds of the components contained in the substrate [26] Meanwhile, according to Madigan et al., [27] that the low solubility of oxygen in water and replacement of oxygen through slow diffusion are growth-inhibiting factors. aerobic living bacteria. The results of this study indicate that the most appropriate concentration for the production of the enzyme mannanase from Bacillus cereus V9 with palm kernel meal substrate is at a substrate concentration of $1 \%$.

\section{CONCLUSION}

This study concludes that palm kernel meal can be used as a $1 \%$ substrate as a substitute for locust bean gum in the production of the enzyme mannanase from Bacillus cereus V9.

\section{ACKNOWLEDGMENTS}

The author would like to thank the Rector of Universitas Jambi, Chair of the Jambi University Research and Community Service Institute, and the Dean of the Faculty of Animal Science for allowing this research to be carried out. This research was funded by DIPA PNBP Institute for Research and Community Service of Universitas Jambi's Leading Applied Research Scheme for Fiscal Year 2020 Number: SP DIPA023.17.2.677565 / 2020 dated 27 December 2019 in accordance with the Research Contract Agreement Number: 484 / UN21.18 / PG / SPK / 2020

\section{REFERENCES}

[1] A. Purnawan, Yopi, T.T. Irawadi. Production of Manooligomannan from Palm Kernel Cake by Mannanase Produced from Streptomyces Cyaenus. Bio-saintifika: Journal of Biology \& Biology Education, 2017, 9(1), 73-80.

[2] N.F.H.A. Aziz, S. Abbasiliasi, H.S. Ng, P. Phapugrangkul, M.H.A. Bakar, U.J. Tam, J.S. Tan. Purification beta-mannanase derived from Bacillus subtilis ATCC 11774 using ionic liquid as adjuvant in aqueous two-phase system. J. Chromatogr. B, 2007. 1055, 104-112

[3] J.P. Queille, J. Sifakis, Specification and verification of concurrent systems in CESAR, in $\mathrm{M}$. Dezani-Ciancaglini and U. Montanari (Eds.), Proceedings of the 5th International Symposium on Programming, Lecture Notes in Computer Science, vol. 137, Springer, Berlin, Heidelberg, 1982, pp. 337-351. DOI: https://doi.org/10.1007/3-54011494-7_22 
[3] P. Saenphoom, J.B. Liang, Y.W. Ho,T.C. Loh, M. Rosfarizan. Effects of enzyme-treated palm kernel expeller on metabolizable energy, growth performance, villus height, and digesta viscosity in broiler chickens. AJAS, 2013, (26), 537-544.

[4] O. Olaniyi. Effect of beta-mannanase treatment on the nutritive quality of palm kernel meal. African Journal of Mic. Research, 2014, Vol 8 (25) pp : 2405-2410

[5] M.R., Abdollahi, B.J. Hosking, D. Ning, V. Ravindran. Influence of palm kernel meal inclusion and exogenous enzyme supplementation on growth performance, energy utilization, and nutrient digestibility in young broilers. AJAS, 2016, (29) pp: 539-548.

[6] W. L. Chen, M. F. Jahromi, S. C. L. Candyrine, J. B. Liang, N. Abdullah, Z. Idrus. Enzymatic hydrolysis drastically reduces fibre content of palmkernel expeller, but without enhancing performance in broiler chickens. Animal Production Science 59(12)

2131-2137 https://doi.org/10.1071/AN17860

[7] Mairizal , F. Manin, E. Hendalia. The Effect of Giving Probiotics and Palm Kernel Meal Subjected to Enzymatic Hydrolysis with Mannanase on Broiler Growth Performance. Pakistan Journal of Nutrition, 2019, 18: 997-1003. DOI: 10.3923/pjn.2019.997.1003 URL: https://scialert.net/abstract/? doi=pjn.2019.997. $\underline{1003}$

[8] Meenakshi, G. Singh, A. Bhalla, G.S. Hoondal. Solid-state fermentation and characterization of partially purified thermostable mannanase from Bacillus sp. MG-33, Bioresource, 2010, 5(3): 16891701.

https://www.researchgate.net/publication/2865155 63

[9] Mairizal, Y. Marlida, Mirzah, F. Manin. Isolation and Characterization of Mannanase-producing Bacillus cereus Isolated from the Hindgut of Termites. Pakistan Journal of Nutrition, 2018, 17: 116-123. DOI: $\quad \underline{10.3923 / p j n .2018 .116 .123}$ URL: https://scialert.net/abstract/?doi=pjn.2018. $\underline{116.123}$

[10] Sumardi, A. Suwanto, M. Thenawidjaja, T. Purwadaria. Isolation and characterization of mannolytic thermophilic bacteria from palm oil shell and their mannanase enzyme production properties. Biotropia, 2005, 25: pp.1-10. DOI: http://dx.doi.org/10.11598/btb.2005.0.25.211

[11] L.R.S. Moreira, E.X.F. Filho. An overview of mannan structure and mannandegrading enzyme systems. Applied Microbiology and Biotechnology , 2008, 79(2):165-78 DOI: 10.1007/s00253-0081423-4

[12] A.P. Utami, R. Setyaningsih., A. Pangastuti, S. L.A. Sari.. Optimasi produksi enzim selulase dari jamur Penicillium sp. SLL06 yang diisolasi dari serasah daun salak (Salacca edulis) Pros Sem Nas Masy Biodiv Indon . 2019, Vol. 5 (2) pp : 145-149. DOI : 10.13057/psnmbi/m050201

[13] A.K. Ray, A. Bairagi, K.S. Ghosh, S.K. Sen. Optimization of fermentation conditions for cellulase production by Bacillus subtilis CY5 and Bacillus circulans TP3 isolated from fish gut. Acta Ichthyol Piscat. 2007. 37(1):47-53. DOI: 10.3750/AIP2007.37.1.07

[14] M. Mandels, D. Sternberg.. Recent advances in cellulase technology. J. Ferment. Technol. 1976, 54:267-286.

[15] A. Meryandini , R. Anggreandari, N. Rachmania N. Isolasi bakteri mannanolitik dan karakterisasi mannanasenya. Biota, 2008. 13(2) pp : 82-88. DOI: https://doi.org/10.24002/biota.v13i2.2675

[16] G.L. Miller. 1959. Using of dinitrosalicylic acid reagent for determination of reducing sugar. Anal Chem. $1959, \quad 31 \quad$ (3) pp:426-428 https://doi.org/10.1021/ac60147a030

[17] J.S. Yin, Q.L Liang, D.M Li, Z.T. Sun. Optimization of production conditions for $\beta$-mannanaseusing apple pomace as raw material in solid-state fermentation. Ann Microbiol ,2013, 63(1) pp :101108.

https://www.researchgate.net/deref/http $\% 3 \mathrm{~A} \% 2 \mathrm{~F} \%$ 2Fdx.doi.org\%2F10.1007\%2Fs13213-012-0449-0

[18] A.S. Greg, R. A. Proctor. At the crossroads of bacterial metabolism and virulence factor synthesis in Staphylococci. Microbiol. Mol. Biol. Rev. 2009, 73(2): 233. Microbiol Mol Biol Rev, 2009 Jun;73(2):233-48. DOI: 10.1128/MMBR.00005-09

[19] C. Krishna, S.E. Nokes. Predicting vegetative inoculum performance to maximize phytase production in solid-state fermentation using response surface methodology. J Indus Microb Biotec., 2001, 26: 161-170 DOI https://doi.org/10.1038/sj.jim.7000103.

[20] Bierbaum G. Karutz M, Botz DW, Wondrey C. 1994. Production of protease with B. Licheniformis mutans insentive to reppresion of exoenzim biosynthesis. Appl Microbial Biotechnol. 40(5):611-617.

[21] E.M. Dusterhoft, E.M., A.W. Bonte and A.G.J. Voragen. 1993. Solubilisation of non-starch 
polysaccharides from oil seed meals by polysacharide degrading enzymes. Journal of the Science Food and Agriculture, 63: 211-220.

[22] Y.S. Lee, Y. Zhou, I.H. Park , M.R.G.S Chandra, S.C Ahn, and Y.L. Choi. 2010. Isolation and purification of thermostable $\beta$-mannanase from Paenibacillus illinoisensis ZY-08. J Korean Soc Appl Biol Chem 53:1-7. http://dx.doi.org/ 10.3839/jksabc.2020.001

[23] Yopi, A. Purnawan A, A. Thontowi , H. Hermansyah, dan A. Wijanarko. 2006. Preparasi manan dan mananase kasar dari bungkil kelapa sawit. Jurnal Teknologi 4: 312-319.

[24] C.H. Chuan, K. Krishnaiah, C.W. Wong, and J. Janaun. 2006. Palm kernel cake as substrate for $\beta$ Mannanase production by Bacillus subtilis ATCC336 under submerged and solid state fermentation. Proceedings of the 1st International Conference on Natural Resource Engineering \& Technology 182-185

[25] N.A.B.M. Norizan, M. Halim, J. S. Tan, S. Abbasiliasi, M. M. Sahri, F. Othman and A. B. Ari_.2020. Enhancement of beta-mannanase production by Bacillus subtilis ATCC11774 through optimization of medium composition. Molecules 2020, 25, 3516; doi:10.3390/molecules25153516

[26] Purwadaria T, Haryati T, Frederick E, Tangendjaja B. 2003. Optimation of $\beta$ - mannanase production on submerged culture of Eupenicillium javanicum as well as $\mathrm{pH}$ and temperature enzyme characterization. JITV 8 (1).

[27] M.T. Madigan, J.M. Martinko, J. Parker. Brock Biology of Microorganisms. $10^{\text {th }}$ Ed. New Jersey (NJ): Prentice-Hall, Inc.S. 2006. 